\title{
Board Size, Crisis, and Firm Performance: Evidence from Banks
}

\author{
Uri Ben Zion $^{1} \&$ Garen Markarian ${ }^{2}$ \\ ${ }^{1}$ Visiting Professor, Bocconi University, Milan, Italy \\ ${ }^{2}$ Professor, WHU - Otto Beisheim School of Management, Vallendar, Germany \\ Correspondence: Garen Markarian, WHU - Otto Beisheim School of Management, Vallendar. Germany, Tel: \\ 49-2616-5090. E-mail: garen.markarian@whu.edu
}

Received: January 19, 2018

Accepted: February 14, 2018

Online Published: February 28, 2018

doi:10.5539/ijef.v10n4p33

URL: https://doi.org/10.5539/ijef.v10n4p33

\begin{abstract}
A large body of research has found conflicting results on the relation between board size and firm performance, where studies indicate that board size is positively, negatively, or is unrelated to firm performance. Using a global sample of 120,000 banks, this study extends the extant literature in a number of important ways: we find that an inverted U-curve characterizes the board size-performance relation, especially for publicly owned non-EU firms. Second, and in contrast, we find that the negative board size-performance correlation is explained by a rational risk-return relation, where small board firms are riskier and follow non-traditional banking strategies. Consequently, we find that banks with small boards performed poorly during the 2008 global credit crisis.
\end{abstract}

Keywords: board size, governance and performance, bank and governance, crisis

\section{Introduction}

A large body of research examines the relation between board size and firm performance. Both Lipton and Lorsch (1992), and Jensen (1993), argue that when boards are large they are less likely to function effectively, given that it is easier for CEOs to control larger boards. As such, larger boards are presumed to be characterized by higher agency costs, where coordination and free-rider problems lead to self-interest and sub-optimal decisions, and an ensuing lower firm performance. Empirical evidence, starting with Yermack (1996), find an inverse relation between board size and firm performance, controlling for factors affecting performance such as size, growth opportunities, industry characteristics, etc.

Nevertheless, this negative relation has not been consistently forthcoming in extant empirical work. For example, Upadhyay and Sriram (2011) argue that firms with larger boards are more transparent, and consequently have a lower cost of capital. A large number of studies have examined firm performance with respect to board size theoretically, empirically, across various academic disciplines, and using US and non-US datasets. Results have been conflicting: studies have found either that larger boards are detrimental to firm performance, or have found a positive relation, or no relation at all (Note 1).

This study extends the literature in a number of ways: first, we examine the relation between board size and firm performance for the banking industry, an important industrial grouping that, to the best of our knowledge, has not been definitively examined in this respect. We examine an extensive global bank database of public and private firms, providing more generalizable and nuanced evidence. We find that an inverted U-curve characterizes the board size-performance relation, especially for publicly owned non-EU firms. In contrast, we find that the negative board size-performance link is explained by a rational risk-return relation, where small board firms are riskier and follow non-traditional banking strategies. Consequently, we find that banks with small boards performed poorly during the 2008 global credit crisis.

Using a global sample of banking firms of about 120,000 observations spanning the years 1990-2013, we find a robust relation between board size and performance. We measure board size as the number of directors sitting on the board (whether insiders or outsiders), we measure firm performance using return on assets, ROA (alternatively, using return on equity, with similar results). At the univariate level, we conduct t-tests examining the mean ROA between firms in the first quartile vs. the last quartile in terms of board size. We find that banks with small boards have a mean ROA of about $1.33 \%$, statistically larger than those with large boards, which have a mean ROA of $0.89 \%$. 
We next examine this performance differential throughout our sample period, where we find that banks with small boards outperform large board firms in every single year of our sample period. Moreover, firms with smaller boards outperformed their large board counterparts by at least $1 \%$ at the height of the boom (2006), and maintained the difference during the crisis by 0.5 percentage points. However, our results also indicate that although on average small board banks perform better, the higher standard deviation of performance resulted into a much larger incidence of losses during the crisis period.

In our multivariate analysis, we find that ROA is positively related to the size of the board, while it is negatively related to the squared term of board size, indicating that the relation takes the shape of an inverted u-curve. This result is robust to firm size, leverage, and year, industry, and country effects. This result is also robust to various statistical specifications and supplemental tests. We also find that banks with small boards have higher investments in debt and equity investments, have a higher deviation of ROA, higher leverage, and pay less dividends. As such, they are riskier. In turn, banks with small boards experienced larger losses, write-offs and impairments, and cut dividends more frequently during the crisis period. Moreover, we find that our board size-performance relation is concentrated for listed firms, providing for an agency explanation, but do not hold for EU-based banks. This perhaps is an outcome of the unique ownership/governance structure of European capital markets (Brunello et al., 2003; Zingales, 1994).

Our study adds to this literature by examining an additional aspect of bank governance, i.e., board size. Our results help explain Berger and Bouwman (2013), who argue that banks with higher levels of capital better survived the crisis. We identify another factor in the bank survival equation, namely, board size and governance, as banks with larger boards had higher capital in the run-up to the crisis. Cheng (2008) argues that firms with larger boards are characterized by a lower performance variability. We extend those results to the banking sector by documenting risks' effect on performance, with a special emphasis on the crisis period. Our study also contributes to the literature that addresses the governance related causal factors that affected the 2008 meltdown. Aebi et al. (2012) argue that banks with better governed risk functions exhibited better performance during the crisis, while Erkens et al. (2012) argue that firms with more independent boards had poorer performance. Finally, our study extends the small sample study of Adams and Mehran (2012) that examines 35 banks, to a more nuanced global sample of banks.

Our results have important policy implications given the prevailing political/regulatory post-crisis. The mortgage credit boom and the subprime crisis that followed have resulted in an extraordinarily large scale of impairment and credit related write-downs, on assets held by banks in the US and around the world (IMF, 2009). A key question is why credit traders and bank management, who were well aware that benign credit conditions could not last forever, did not take steps to limit their exposure before the boom eventually ended. Corporate governance arrangements have been viewed as one of the main explanations from politicians (Note 2), regulators (Note 3), and governance experts (Note 4). Our results shed light on the role of corporate governance during the crisis. Specifically, we show that banks with larger boards performed better in 2008. Our results indicate that it is true that firms with smaller boards perform better, on average and over the whole sample period, but this is fully explained by a rational risk-return relation. Consequently, any policy recommendation to reform boards need to account for the notion that having smaller boards does not necessarily mean better performance.

Our paper is organized as follows, the next section discusses the prior literature, while section 3 presents the sample selection, variables, and descriptive. Section 4 presents the research design, main results, and auxiliary analysis. Section 5 concludes.

\section{Prior Literature}

\subsection{Board Size and Firm Performance}

Since Jensen's (1993) proposition that larger boards are subject to agency costs and are less efficient from a performance perspective, a host of studies have examined the issue in various settings, both empirically and analytically. These studies are too numerous to discuss in the current manuscript, as such, we examine only a select few. Nevertheless, these studies can be classified into three broad categories: those that find empirical support for Jensen's proposition, those that find that larger boards perform better, and those that do not find a significant relation.

From the earlier empirical works that are supportive of a negative board size to performance relation, Yermack (1996) finds that firm performance, measured both by Tobin's Q and ROA, and is decreasing in board size. He furthermore finds that compensation related incentives of the CEO are correspondingly higher, and that smaller boards replace their CEOs faster in times of distress. Eisenberg, Sundgren, and Wells (1998) extend these results into small Finnish firms, hence confirming a similar relation in a different organizational, cultural and legal 
setting. Beiner, Drobetz, Schmid, and Zimmermann (2003), examine the setting of small closely held firms, where they find that board size is related to the number of children of the CEO. Furthermore, they find a small negative effect between the size of the board, as characterized by more than six members, and performance. Conyon and Peck (1998) examine firms from the United Kingdom, France, the Netherlands, Denmark, and Italy. Although they find a negative relation, the significance is not consistent across all their specifications. Cheng (2008), provide evidence on the board size-performance relation, where they argue that due to decision making dynamics, larger boards are less likely to find compromises on extreme cases, and hence, corporate performance is more stable.

In contrast, Lehn, Patro, and Zhao (2009) examine 82 US companies for a 65-year period, where they show that controlling for firm size, growth opportunities, geographical expansion, and merger activity, the board size performance relation disappears. Beiner, Drobetz, Schmid, and Zimmermann (2003) argue, and find that, board size is an independent governance construct, invariant to board structure, however, they do not find a negative relation between board size and performance. Moreover, Coles et al. (2008) argue that the relation between board size and performance is positive for complex firms. Finally, in a meta-analysis, Dalton, Daily, Johnson, and Ellstrand (1999), find that board size and performance are positive related.

This study extends the literature by examining the relation between board size and firm performance for the banking industry, an important industrial grouping that has been scarcely examined in this respect. Given that prior studies have ignored financial firms, this study provides an interesting platform to see whether our notions regarding board size and performance are industry specific. Moreover, we examine both private and public firms, and US and international firms. Providing broader results, and affording comparisons. Our study also shed lights on the governance/crisis debate, providing for a risk-based explanation for the negative board size-performance relation, as discussed in the following section.

\subsection{Governance and the Crisis}

Irrespective of the institutional environment, boards of directors have come under fierce criticism, from all capital markets participants alike. Reports are rife with stories that going into the crisis many boards were ineffective. For example, the Institute of International Finance (2008) concludes that "events have raised questions about the ability of certain boards properly to oversee senior managements and to understand and monitor the business itself".

Moreover, a majority of banks have indicated that their boards were not properly knowledgeable about their bank's risk management. Although in that regard, NYSE listing standards clearly prescribe that risk management (and internal controls) are an audit committee responsibility. The empirical evidence to date (although preliminary in nature), offers mixed perspectives regarding the role of governance in the crisis. However, governance responses seem to have been country specific (see Erkens et al., 2010). While Beltratti and Stulz (2010) find no evidence supportive of a relationship between governance and the crisis (a result corroborated by Iyer et al., 2010). In contrast, other studies find a direct relationship between governance structures and the crisis. Francis et al. (2009) find that board members connected to the CEO, relate to lower crisis returns, and Chesney et al. (2010) find that less independent boards led to higher write-downs.

Our study complements, and adds to the studies above by examining the board size-performance relation during times of distress, utilizing board size as proxy for one aspect of governance. Examining the relation between board size and performance during the crisis, provides a strong "shock test" for the efficacy of governance, which could be masked during times of normal operations.

\section{Sample Selection, Variables and Descriptives}

\subsection{Sample Selection}

Our simple is drawn from the firms covered in the Bureau Van Dijk Bankscope Global Banking database, which covers the period 1990 to 2013: the start date of Bankscope, and the last year of complete data available (although the first three years contain much less observations than the rest of the sample period). The end year is 2013 reflecting the last year of full data available for our analysis (Note 5). Bankscope covers a global sample of public and private banks, with 3,000 banks a year in the early years, and up to about 10,000 banks a year in the later years. The database reports data from the financial statements of banks, and a number of footnote items. It also provides data on the size of the board of directors, the only governance variable that it reports, without further information on its composition and other details. Board size does not significantly vary in our sample similar to other studies utilizing board size as a proxy for governance (see Yermack, 1996) (Note 6). It also does not report firm market values (more than half the sample is composed of privately held firms), as such, our study 
on performance is restricted to accounting measures of performance.

To explain our sample further, we report descriptives on a variety of dimensions. Table 1 reports the sub-industrial composition of our firms. After eliminating all governmental banks (central banks, state owned mortgage banks, state owned credits banks, etc.), the biggest four sub-categories are commercial, cooperative, savings, and bank holding companies, comprising $47 \%, 15 \%, 12 \%$, and $10 \%$ of the sample. The rest of the industrial composition, which has categories such as mortgage, Islamic, investments banks, etc., is more dispersed, and not a single category comprises more than $5 \%$ of the total. The total sample is about 123,000 firm-years comprised of about 38,000 distinct banks.

Table 1. Sub-industrial composition of sample firms

\begin{tabular}{lcc}
\hline Sub-Industry & Frequency & Percent \\
\hline Commercial Banks & 53,024 & 43.17 \\
Cooperative Bank & 19,348 & 15.75 \\
Savings Bank & 14,127 & 11.50 \\
Bank Holding Companies & 12,151 & 9.89 \\
Investment Banks & 6,564 & 5.34 \\
Real Estate / Mortgage Bank & 3,863 & 3.15 \\
Finance Companies (Credit Card, Factoring) & 4,112 & 3.35 \\
Private Banking and Asset Management & 3,456 & 2.81 \\
Other & 6,181 & 5.03 \\
Total & 122,826 & 100 \\
\hline
\end{tabular}

Next we examine the sample composition by country in Table 2 . The four most represented countries are Germany, USA, Italy, and the United Kingdom, comprising 15\%, 8\%, 8\%, and 6\% of the sample. The rest of the countries represent less than 5\% of the sample each, and in total, 199 countries are represented. Our results are not sensitive to any particular country or region, and we examine our main results in US vs. non-US, for EU vs. non-EU, and non US/EU partitions.

Table 2. Geographic distribution of sample banks

\begin{tabular}{lcc}
\hline GERMANY & 18,323 & 14.92 \\
USA & 10,448 & 8.51 \\
ITALY & 9,942 & 8.09 \\
UNITED KINGDOM & 6,973 & 5.68 \\
SWITZERLAND & 5,734 & 4.67 \\
FRANCE & 4,927 & 4.01 \\
JAPAN & 4,049 & 3.3 \\
RUSSIA & 2,798 & 2.28 \\
AUSTRIA & 2,723 & 2.22 \\
SPAIN & 2,288 & 1.86 \\
DENMARK & 1,952 & 1.59 \\
NORWAY & 1,876 & 1.53 \\
HONG KONG & 1,532 & 1.25 \\
MALAYSIA & 1,517 & 1.24 \\
LUXEMBOURG & 1,499 & 1.22 \\
ARGENTINA & 1,404 & 1.14 \\
BELGIUM & 1,369 & 1.11 \\
BRAZIL & 1,350 & 1.1 \\
SWEDEN & 1,342 & 1.09 \\
NETHERLANDS & 1,301 & 1.06 \\
AUSTRALIA & 1,244 & 1.01 \\
INDIA & 1,207 & 0.98 \\
OTHER & 37,028 & 30.14 \\
\hline Total & 122,826 & 100 \\
\hline
\end{tabular}




\subsection{Variables and Descriptives}

Given that our study examines the relation between governance and firm performance, we utilize a number of variables that are relevant for our purposes. Bankscope reports data only on board size, without further elaboration on its structure and composition, hence we utilize board size as our proxy for firm-level corporate governance (BoardSize). Given that this variable is heavily right skewed we use a log transform in all our multivariate tests, although not doing so does not change our inferences. As our main measure of firm performance we utilize ROA, defined as net income divided by the average assets of the last two years (utilizing return on equity yields qualitatively similar results). We also calculate Assets which is the book value of assets, since firm performance in the banking sector is heavily influenced by firm size (Boyd \& Runkle, 1993). We calculate Leverage as one minus total book value of equity divided by the book value of assets, given that leverage and firm performance are correlated, especially during crises (Berger \& Bouwman, 2013). We also calculate Cash which is cash at hand (and other temporary, liquid, and risk-free investments) divided by total assets. To control for a bank's strategic orientation and investment strategy (see Livne et al., 2013), we calculate a number of variables. Trading measures the extent of off-balance sheet items, again as a percentage of assets. We calculate Loans, which measures the percentage of assets that are composed of loans, to control for bank strategic orientation. Finally, FixedAssets is the amount of tangible assets reported by Bankscope, normalized by total assets. Descriptives of these variables are presented in Table 3. We utilize a large number of other variables in our tests, and are discussed in their relevant sections.

Table 3. Descriptive statistics for select variables

\begin{tabular}{lcccccc}
\hline \multicolumn{1}{c}{ Variable } & $\mathbf{N}$ & Mean & Median & St.Deviation & p25 & p75 \\
\hline BoardSize & 122,826 & 12.13098 & 10 & 7.65 & 7 & 15 \\
ROA & 121,896 & 1.13 & 0.67 & 2.70 & 0.22 & 1.46 \\
Assets (in billions) & 122,826 & 16.31 & 1.16 & 56.43 & 0.29 & 5.92 \\
Leverage & 122,826 & 0.91 & 0.86 & 0.168 & 0.86 & 0.94 \\
Cash & 116,528 & 0.040 & 0.019 & 0.063 & 0.007 & 0.040 \\
FixedAssets & 129,299 & 0.021 & 0.012 & 0.040 & 0.0055 & 0.023 \\
Loans & 118,020 & 0.538 & 0.581 & 0.240 & 0.389 & 0.710 \\
\hline
\end{tabular}

Note. BoardSize is the number of members sitting on a board; ROA is return on assets: Assets is the book value of assets at fiscal year-end; Leverage is one minus the book value of equity, normalized by total assets; Cash is the cash balance at year end, normalized by total assets; FixedAssets is the total book value of physical non-investable assets, normalized by total assets; Loans is the net book value of loans normalized by total assets. The time period is 1990-2013.

We see that mean BoardSize is 12, indicating that the average board is composed of 12 directors. The standard deviation is 7.65, indicating that in the majority of firms, boards are comprised of less than 25 directors. Mean $R O A$ is $1.13 \%$, while the median is $0.67 \%$, indicating that there is a positive skew in our sample, and that firms are profitable in general. Leverage is about $91 \%$, a high leverage ratio that is typical of banks. Fixed assets are about $1-2 \%$ of total assets, a low number that exemplifies bank operating structures. The same can be said about cash holdings. Loans has a mean of $54 \%$, which in a traditional view, is the main operating activity of a bank.

\section{Research Design and Results}

\subsection{Research Design}

This paper investigates the relation between board size and performance. This is done in a number of ways. At the univariate level, we conduct t-tests examining the return on assets of firms with large boards and compare them to firms with small boards. At the multivariate level, we conduct a regression analysis of the following form:

$$
\text { ROA }_{i, t}=\log \text { BoardSize }_{i, t}+\log \text { BoardSize }_{i, t}^{2}+\log _{\text {Assets }}, t+\text { Leverages }_{i, t}+Y+I+C
$$

Variable names are as explained above, while $Y, I, C$ denote dummies variables for year, sub-industry, and country, respectively. Given that prior studies find a nonlinear relation between board size and firm performance, we also include the squared term of board size (adding a squared term for firm size does not alter our inferences). We present a parsimonious econometric model, but ensuing tests utilize a variety of additional controls. We include year controls since they are important because performance varies through time in relation to macroeconomic factors, and could be linked to board size (in fact, we see a general decreasing trend in board size in our sample period). Moreover, there is large variation in governance practices, reforms, throughout the 
sample period, which is captured by year effects. Sub-industry controls are important because board size, performance, and sub-industrial composition could be correlated (in fact, we have no academic evidence regarding relative board sizes across sub-industries in the banking sector). Finally, we include country controls because the governance traditions differ across countries, while country-specific performance could be orthogonal but spuriously correlated to it. Our main estimation method is OLS clustering by firm, but our results are robust to using a Fama-MacBeth estimation procedure (Fama \& MacBeth, 1973), or clustering for both firm and year, following the methodology suggested by Thompson (2006) and by Cameron et al. (2006). ${ }^{7}$

\subsection{Univariate Results}

We start by presenting the univariate analyses. We first conduct t-tests examining the mean ROA between large vs. small board firms (comparing median returns yields similar inferences). We utilize the breakdowns in our descriptive analysis to define large boards as those that have 15 board members or more (more than $75 \%$ of our distribution), conversely, we define as small boards those that have 7 members or less (the first $25 \%$ of our distribution). We conduct t-tests on the median ROA of those two sub-samples. Results are presented in Table 4.

Table 4. Univariate analysis examining the relation between governance and performance

\begin{tabular}{|c|c|c|c|c|}
\hline Panel A (all years): & Observations & Mean & Std. Err. & Std. Dev. \\
\hline \multicolumn{5}{|l|}{ Group } \\
\hline Small Board ROA & 40,422 & 1.33 & 0.017 & 3.30 \\
\hline Large Board ROA & 33,266 & 0.89 & 0.011 & 2.14 \\
\hline \multirow[t]{3}{*}{ Difference } & & 0.43 & & \\
\hline & \multicolumn{3}{|c|}{$\mathrm{t}=20.43$} & \\
\hline & \multicolumn{3}{|c|}{$\operatorname{Pr}(\mathrm{T}>\mathrm{t})=0.00001$} & \\
\hline Panel B $($ Year $=2008)$ & Observations & Mean & Std. Err. & Std. Dev. \\
\hline \multicolumn{5}{|l|}{ Group } \\
\hline Small Board $\triangle R O A$ & 2744 & -0.96 & 0.063 & 3.42 \\
\hline Large Board $\triangle \mathrm{ROA}$ & 1865 & -0.53 & 0.040 & 1.80 \\
\hline \multirow[t]{3}{*}{ Difference } & & -0.41 & & \\
\hline & \multicolumn{3}{|c|}{$\mathrm{t}=-5.11$} & \\
\hline & \multicolumn{3}{|c|}{$\operatorname{Pr}(\mathrm{T}>\mathrm{t})=0.00001$} & \\
\hline
\end{tabular}

Note. Large board is defined as those above the $75 \%$ of the sample distribution (Board Size $>15$ members), and small board are those that are below the $25^{\text {th }}$ percentile (Board Size $<8$ members). The time period is 1990-2013.

In Panel A, we compare mean $R O A$ for large vs. small board groupings. Results indicate that banks with small boards have a mean $R O A$ of about $1.33 \%$, while those with large boards have a mean $R O A$ of $0.89 \%$. This difference is statistically significant at less than $1 \%(t$-statistic $=20.43)$. In Panel B, we specifically look at performance during the crisis (fiscal year 2008), and we examine the change in ROA for each of our governance categories in order to establish the performance outcomes for firms with differential governance structures. For the same BoardSize groupings as above, we see contrasting results, companies with smaller boards have a mean change in $R O A$ of about $-0.96 \%$ (essentially wiping out $70 \%$ of the mean returns for average small board size firms), while banks with large boards have a mean $R O A$ of $-0.53 \%$ (60\% of mean returns). This difference is again statistically significant at less than $1 \%(t$-statistic $=-5.11)$. In addition to the mean differential of $R O A$ and chROA between large and small board size firms, it is of note that the standard deviation in performance of smaller board firms is substantially higher (by around 70\%). Specifically in the year 2008, we see that the standard deviation of chROA for small board firms is 3.42 (mean ROA being 1.33 throughout the period). Not surprisingly, 504 small board banks have a negative ROA in 2008, in contrast to only 259 negative ROAs for large board firms.

In unreported results we observe that the change in ROA is statistically insignificant between large vs. small board firms in the years 2007 and 2009, this is as expected, since write-downs and large losses were concentrated in the 2008 period, and subsequently cleaned up balance sheets did not yield a differential impact on the income statement. In sum, there is a statistically differential performance between large vs. small board firms, where smaller board firms on average perform better than larger board ones. Nevertheless, the data also indicates that this performance differential is not consistently sustained, as it reverses during the 2008 crisis, perhaps indicating that the risky strategies adopted by smaller firms yielded poor performance during distress times. 
As further univariate evidence regarding the role of governance in performance, and to improve the descriptives, we graphically examine the relation between governance and performance throughout our sample period, as presented in Figure 1.

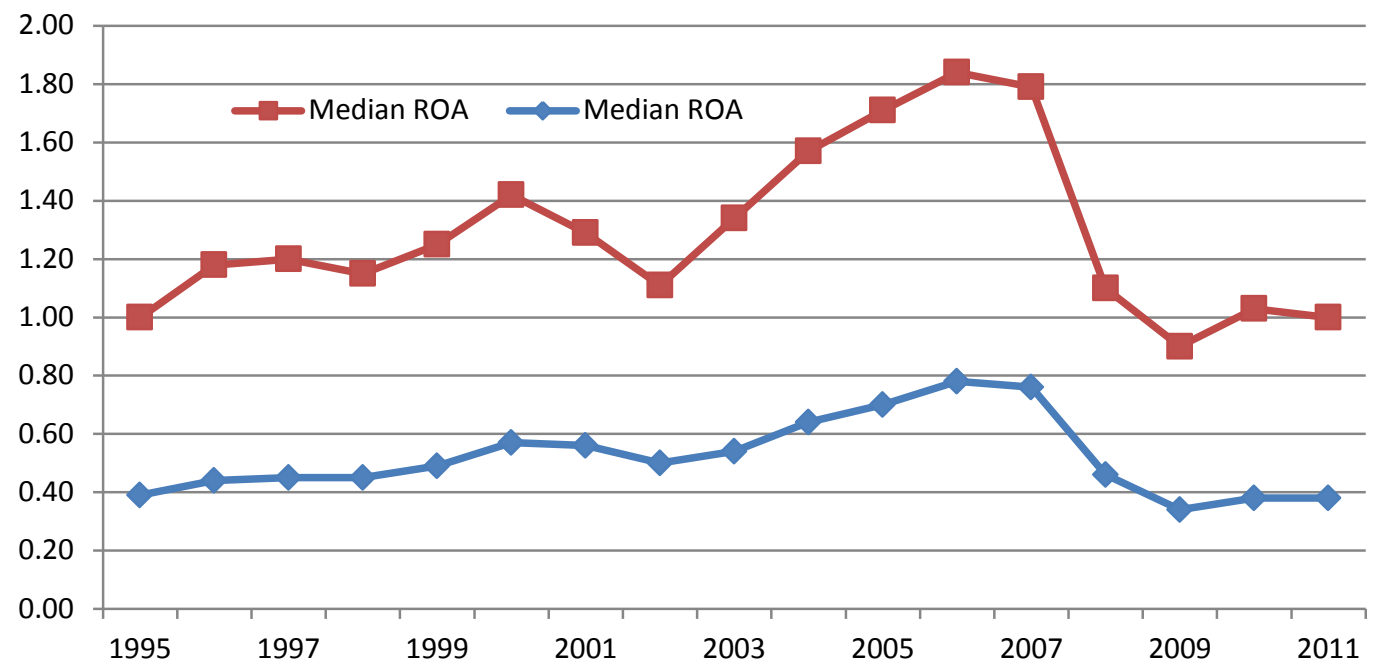

Figure 1. Time-series relation of board size and $R O A$

Note. Large board is defined as those above the $75 \%$ of the sample distribution (Board Size $>15$ members), and small board are those that are below the $25^{\text {th }}$ percentile (Board Size $<8$ members).

We see that firms with small boards outperform large board firms in every single year of our sample period. Moreover, they outperformed by at least 2 percentage points at the height of the boom (2006), and maintained the difference during the crisis by at least 0.75 percentage points. However, if look at the pattern in chROA we see that performance changes are highly more volatile for small board banks (see Figure 2), where positive increases for small board firms are larger during the boom (2003-2006), the recovery (2010), but they are also much lower during the crisis year (2008) (Note 8). In sum, results on this graphical analysis confirm the univariate results obtained above.

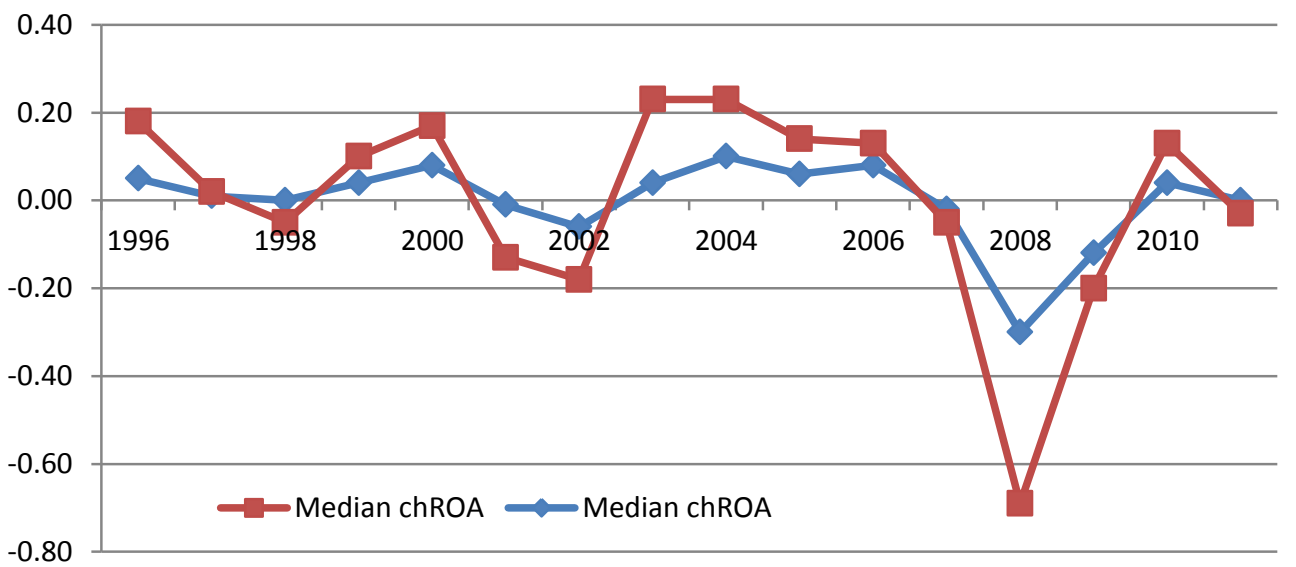

Figure 2. Time-series relation of board size and the change in $R O A$

Note. Large board is defined as those above the $75 \%$ of the sample distribution (Board Size $>15$ members), and small board are those that are below the $25^{\text {th }}$ percentile (Board Size $<8$ members).

As a final analysis at the univariate level, and to examine what constitutes an "optimal" board size, we graphically plot $R O A$ as a function of board size. Results are presented in Figure 3. 


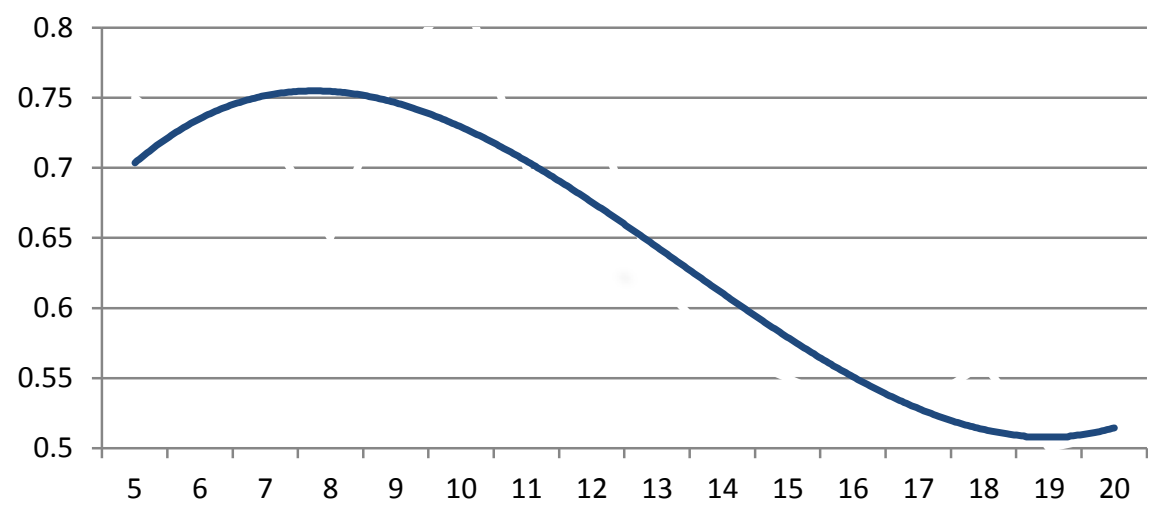

Figure 3. Board size and ROA for listed firms

Note. The figure plots the relation between the number of board members (x-axis) vs. ROA (y-axis).

We plot all data-points with at least 1,000 observations per each board size value, starting with a board size of 5 . Graphical fitting of a polynomial trend-line indicates an inverted U-curve, where we see that performance increases as board size becomes larger, and decreases with boards larger than 9 . With these preliminary graphical and univariate representations, and given the limitations of such analysis and the effects of confounding cross-correlations, we next turn our attention to our multivariate analysis.

\subsection{Multivariate Results}

\subsubsection{Board Size and Firm Performance}

In our multivariate analysis, we follow the procedure of Yermack (1996), and regress firm performance on board size and control variables, as explained in the research design section. Table 5 presents our results. In Model (1) we regress ROA on logBoardSize, $\log$ BoardSize $^{2}, \log$ Assets, Leverage, and year, sub-industry, and country dummies. Consistent with prior research, we find that both terms proxying for governance are significant with $\operatorname{logBoardSize}$ positive and significant $(t$-statistic $=4.53)$, while $\operatorname{logBoardSize} e^{2}$ is negative and similarly significant $(t$-statistic $=-4.74)$. Hence, an inverted U-curve relation between board size and return on assets. Given the conflicting results in prior research that examines board size and performance, our study falls in the camp of those studies that find an initially increasing, and subsequently decreasing, relation between board size and firm performance (Note 9).

Regarding our control variables, results are as expected. logAssets is positive and significant ( $t$-statistic ranging between 7 and 15, depending on the model utilized), indicating that larger banks are more profitable, and augmenting prior studies that argue economies of scale are of prime importance in the banking sector (see Berger \& Humphrey, 1997) (Note 10). Leverage is negative, indicating that the average bank is over-levered, and interest revenue and returns on other bank activities (trading, etc.), exceed the cost of servicing deposits and liabilities. Only in Model (4) is Leverage positive and marginally significant $(t$-statistic $=1.79, \mathrm{p}<10 \%)$, explained by the fact that there is a mechanical relation between $R O E$ and leverage.

Table 5. Multivariate analysis examining the relation between governance and firm performance

\begin{tabular}{lcccc}
\hline & $(1)$ & $(2)$ & $(3)$ & $(4)$ \\
VARIABLES & $\boldsymbol{R O A}$ & $\boldsymbol{R O A}$ & $\boldsymbol{R O A}$ & $\boldsymbol{R O E}$ \\
\hline Constant & -1.5933 & $-1.8549^{* * *}$ & -1.3412 & 5.6537 \\
& {$[-0.97]$} & {$[-3.158]$} & {$[-1.094]$} & {$[1.43]$} \\
$\operatorname{logBoardSize}$ & $0.5064^{* * *}$ & $0.3609^{* * *}$ & $0.8803^{* *}$ & $1.4005^{* *}$ \\
& {$[4.534]$} & {$[2.681]$} & {$[2.136]$} & {$[2.133]$} \\
$\log$ BoardSize & $-0.1181^{* * *}$ & $-0.0830^{* * *}$ & $-0.1513^{* *}$ & $-0.3598^{* * *}$ \\
& {$[-4.743]$} & {$[-2.791]$} & {$[-2.271]$} & {$[-2.476]$} \\
$\log$ Assets & $0.0843^{* * *}$ & $0.0859^{* * *}$ & $0.0751^{* * *}$ & $0.7907 * * *$ \\
& {$[8.806]$} & {$[7.018]$} & {$[7.762]$} & {$[15.073]$} \\
Leverage & $-5.8131^{* * *}$ & $-5.4290^{* * *}$ & $-5.7876^{* * *}$ & $1.1032^{*}$ \\
& {$[-26.873]$} & {$[-21.179]$} & {$[-26.146]$} & {$[1.794]$} \\
\hline
\end{tabular}




\begin{tabular}{lcccc}
\hline Year & Yes & Yes & Yes & Yes \\
Industry Controls & Yes & Yes & Yes & Yes \\
Country Controls & Yes & Yes & Yes & Yes \\
Observations & 125,684 & 71,478 & 119,561 & 125,581 \\
R-squared & 0.207 & 0.186 & 0.138 & 0.120 \\
\hline
\end{tabular}

Note. Model (1) employs ROA as the dependent variable. Model (2) re-runs the analysis for only firms with board sizes larger than 15 or less than 8. Model (3) demeans ROA by each country/year partition. Model (4) examines ROE. ROA is return on assets, BoardSize is the number of directors sitting on board, Assets is the book value of assets, Leverage is one minus the book value of equity normalized by total assets. *, **, *** indicate significance at $1 \%, 5 \%$, and $10 \%$ respectively. All regressions are conducted using OLS and clustering bank id. The time period is $1990-2013$.

In Models (2)-(4) we present variations on our main regression result. In Model (2) we use the sub-sample of firms where board size is either more than 15 or less than 8 (the $25^{\text {th }} \& 75^{\text {th }}$ of the distributions), we do this to examine whether the inverted U-curve relation between board size and firm performance is concentrated at the tail end of the distribution. We find that this is so: results in Model (2) are significant with similar inferences as to Model (1). In contrast, unreported results indicate that if we re-run this analysis for the middle part of the distribution (board size between 8 and 15), results are not significant. This indicates that for a firm with an "average" distribution, board size does not matter for performance. Positive (negative) board/performance effects result from firms that increase board size if board size is small (large) ex-ante. These results perhaps help explain the conflicting results in the prior literature: depending on the deviation from an "optimal" ratio: board size effects on firm performance could be either negative, positive, or non-significant. Hence, board size-performance studies are highly sensitive to the samples utilized.

In Model (3) we present a further refinement of our analysis in Model (1). Our dataset has two unique features: (a) there is large variation in mean bank board size across countries (mean board size in the UK is 9, while it is 15 in South Africa and 17 in Italy), and (b) Bankscope heavily increases its coverage of small banks and non G-10 banks (i.e. group of 10 leading economies) in the second half of our sample period. Although we use year and country fixed effects, our analysis is incomplete if results are sensitive to the construction of our sample. To provide for a finer analysis, we de-mean board size by each country/year partition, and re-run our analysis. We see that inferences remain unchanged. Finally, in Model (4) we repeat our analysis in Model (1) by using $R O E$ rather than $R O A$ as the dependent variable: inferences remain unchanged.

\subsubsection{Board Size and Firm Characteristics}

Results above indicate a consistent and robust relation between board size and performance. These results are intriguing, but are incomplete given that they do not answer the underlying causal drivers for such a relation. In order to do so we next examine the relation between board size and firm characteristics, as results should be attributed to the differential strategies adopted by banks with dissimilar boards. Consequently, we look at the composition of a bank's balance sheet (loans, mortgages, trading assets, etc.) and riskiness (leverage, variability of reported performance, payout ratio, etc.). In Table 6 we examine the relation between board size and bank characteristics and investment patterns. In Table 7 we examine the relation between board size and firm risk. Given that our interest is to relate board size to firm characteristics, we no more investigate the squared term of board size in these set of tests.

Given the large number of bank characteristics that could be potentially interesting, we examine items from both the income statement and the balance sheet. We first examine three income statement items. In Model (1) we examine the relation between board size and the net interest margin earned on loans (NetInterestMargin), we see that this relation is positive. This indicates that on average, firms with larger boards either have a lower cost of capital, or lend out riskier loans. This issue will be further examined below in Model (5).

Table 6. Multivariate analysis examining the relation between governance and firm characteristics

\begin{tabular}{lcccc}
\hline & $(1)$ & $(2)$ & $(3)$ & $(4)$ \\
VARIABLES & Net Interest Margin & Other Income & Personnel Expenses & Fixed Assets \\
\hline Constant & $9.5478^{* * *}$ & $9.3080^{* * *}$ & 0.0497 & $0.0367^{* * *}$ \\
& {$[11.839]$} & {$[3.385]$} & {$[0.001]$} & {$[9.348]$} \\
logBoardsize & $0.0944^{* *}$ & $0.1368^{* *}$ & $0.0016^{* * *}$ & $0.0016^{* * *}$ \\
& {$[2.367]$} & {$[2.013]$} & {$[6.255]$} & {$[5.562]$} \\
\hline
\end{tabular}




\begin{tabular}{|c|c|c|c|c|}
\hline \multirow[t]{2}{*}{ logAssets } & $-0.2401 * * *$ & $-0.2510 * * *$ & $-0.0022 * * *$ & $-0.0014 * * *$ \\
\hline & [-18.377] & [-9.113] & [-20.993] & {$[-13.422]$} \\
\hline \multirow[t]{2}{*}{ Leverage } & $-2.9245^{* * *}$ & $-11.3636^{* * *}$ & $-0.0368 * * *$ & $-0.0237 * * *$ \\
\hline & {$[-11.623]$} & {$[-19.010]$} & {$[-14.970]$} & {$[-10.752]$} \\
\hline Observations & 122,668 & 122,008 & 111,133 & 122,450 \\
\hline \multirow[t]{2}{*}{ R-squared } & 0.385 & 0.273 & 0.323 & 0.276 \\
\hline & (5) & (6) & (7) & $(8)$ \\
\hline VARIABLES & Loans & Trading Assets & Securities & Earning Assets \\
\hline \multirow[t]{2}{*}{ Constant } & 0.7318 & 0.0621 & 0.1844 & $0.1867 * *$ \\
\hline & {$[0.004]$} & [0.005.] & [0.056] & [2.476] \\
\hline \multirow[t]{2}{*}{ logBoardsize } & 0.0011 & $-0.0062 * * *$ & $-0.0118 * * *$ & $-0.0067 * *$ \\
\hline & {$[0.374]$} & [-5.589] & [-4.524] & {$[-2.110]$} \\
\hline \multirow[t]{2}{*}{ logAssets } & $-0.0060 * * *$ & $0.0021 * * *$ & $0.0083^{* * * *}$ & $0.0091 * * *$ \\
\hline & [-4.961] & [4.773] & [8.332] & [7.599] \\
\hline \multirow[t]{2}{*}{ Leverage } & $0.4225^{* * *}$ & $-0.0257 * * *$ & $-0.1212 * * *$ & $-0.4064 * * *$ \\
\hline & [25.839] & {$[-5.081]$} & [-7.369] & {$[-27.757]$} \\
\hline Observations & 122,131 & 127,255 & 118,599 & 126,580 \\
\hline R-squared & 0.341 & 0.318 & 0.213 & 0.314 \\
\hline
\end{tabular}

Note. ROA is return on assets, BoardSize is the number of directors sitting on board, Assets is the book value of assets, Leverage is one minus the book value of equity normalized by total assets, Net Interest Margin is interest revenue minus interest expense, Other Income is total operating income minus net interest revenue, Personnel Expenses are total employee costs, Fixed Assets is total net value of tangible operating property, Loans is the total value of outstanding loans, Trading Assets are assets held in the balance sheet for the purpose of short term trading, Securities are investments in debt and equity securities, Earning Assets are all invested assets including loans and securities. All dependent variables are normalized by total assets. $*$, **, *** indicate significance at $1 \%, 5 \%$, and $10 \%$ respectively. All regressions are conducted using OLS and clustering on bank id. All regression include country, year, and sub-industry fixed effects. The time period is 1990-2013.

In Model (2) we examine OtherIncome which is calculated as the difference between total operating income minus net interest revenue, normalized by total assets. We see that this variable is also positively related to board size. In Model (3) we see similar results on PersonnelExpenses which is also positively and significantly related to board size. Results on an analysis of income statement items reveal that firms with larger boards enjoy both higher net revenues on loans and other income, but simultaneously have a higher employee wage bill. In untabulated results, we see that firms with larger boards also pay a higher tax rate (calculated as tax expense normalized by pre-tax income), providing for a political cost explanation (Zimmermann, 1983).

We next focus on the balance sheet because it is of prime importance in the banking sector, where in contrast to a dot.com firm, biotech, or even a retail firm, the composition of assets does not clearly indicate strategies and ensuing profitability. For a bank, investing in certain assets, or transaction structuring, or the riskiness of a loan and trading portfolio, are activities that may be reflected in the balance sheet before they are fully reflected in the income statement. The composition and quality of a bank's assets have a direct impact on the bank's ability to trade, generate future cash flows, and avoid infringing regulatory capital requirements.

In Model (4) we examine the relation between board size and FixedAssets, calculated as the total value of tangible operating property a bank owns normalized by total assets (i.e., retail banking units). Results indicate that this is positively related to logBoardSize. In Model (5) we examine the relation between board size and Loans, defined as the total value of outstanding loans normalized by total assets: results are insignificant (Note 11). In Model (6) we examine TradingAssets which are assets held in the balance sheet for the purpose of short term trading, with changes in value taken to income and reported as trading income. Results indicate that board size is negatively and significantly related to trading assets (although in unreported results there is no relation between board size and yield from investments in trading assets). In Model (7) we examine the relation to investments in debt and equity securities, where similar to trading assets in Model (6), the relation to board size is negative. Finally, in Model (8) we see that total earning assets is negatively related to board size.

In sum, results in Table 5 indicate that banks with large boards are structurally different than banks with small boards. Although the incidence of loans is the same across both categories, the evidence broadly indicates that banks with large boards have a higher retail customer presence with a higher incidence of personnel and tax costs, enjoy a lower cost of capital, and have larger investments in fixed assets that correspondingly affect income through the depreciation channel. In contrast, banks with large boards do not have investments in debt and equity 
securities, and generally have lower investments in earnings generating assets.

\subsubsection{Board Size and Firm Risk}

Results in Table 6 indicate a general riskiness of banks with smaller boards. They have less fixed assets, and have a higher incidence in debt and equity securities. Banks hold securities for several reasons, such as proprietary trading, when they act as dealers or market makers in financial markets, or as a part of short-term liquidity management. Many view trading assets as speculative in nature (e.g., Stickney et al., 2010, p. 573). Nevertheless, in the analysis above, the relation to risk is an indirect one. In this section, we examine the relation between board size and risk directly. Table 7 presents our results.

Table 7. Multivariate analysis examining the relation between governance and firm risk

\begin{tabular}{lccc}
\hline & $(1)$ & $(2)$ & $(3)$ \\
VARIABLES & Leverage & Deviation-ROA & Dividends \\
\hline Constant & $-0.9391^{* * *}$ & $1.2720^{* * *}$ & -0.0062 \\
LogBoardsize & {$[-16.901]$} & {$[3.046]$} & {$[]$.} \\
& $-0.0150^{* * *}$ & $-0.1147^{* * *}$ & $0.00045^{* * *}$ \\
logAssets & {$[-7.306]$} & {$[-5.245]$} & {$[4.419]$} \\
& $0.0341^{* * *}$ & $-0.0532^{* * *}$ & 0.0007 \\
Leverage & {$[41.530]$} & {$[-6.346]$} & {$[.267]$} \\
& & $-0.0618^{* * *}$ & $-0.015^{* * *}$ \\
Year Controls & & {$[-32.481]$} & {$[-16.040]$} \\
Industry Controls & Yes & Yes & Yes \\
Country Controls & Yes & Yes & Yes \\
Observations & Yes & Yes & Yes \\
R-squared & 127,255 & 112,038 & 125,683 \\
\hline
\end{tabular}

Note. ROA is return on assets, BoardSize is the number of directors sitting on board, Assets is the book value of assets, Leverage is one minus the book value of equity normalized by total assets. Deviation-ROA is the standard deviation of ROA over the past three years. Dividends is cash paid out to investors normalized by total assets. *, **, *** indicate significance at $1 \%, 5 \%$, and $10 \%$ respectively. All regressions are conducted using OLS and clustering bank id. The time period is 1990-2013.

In Model (1) we regress the log of board size on leverage, given that in the banking sector the strength of the financial position of an entity is particularly important, and the presence of adequate capital is a prime source of riskiness. In Model (1) we see that $\operatorname{logBoardSize}$ is negatively related to Leverage. In Model (2) we examine the relation to standard deviation of ROA, calculated over the prior three year period (Deviation-ROA). We see that $\operatorname{logBoardSize}$ is negative and highly significant $(t$-statistic $=-5.25)$, indicating that firms with larger boards have a less variable performance stream, implying lowered risk. In Model (3) we examine the relation of board size to dividend payouts, where we see that there is a positive relation between logBoardSize and Dividends (t-statistic = 4.42), providing indication that firms with larger boards are ones with stable operations and a commitment to regular payouts, hence lowered riskiness (see Grullon et al., 2002).

Taken together, results in Models (1)-(3) provide evidence that augments the results found in Table 6: banks with larger boards are less risky than their counterparts with smaller boards, as evidenced by lower leverage, lower deviation of ROA, and higher dividend payouts.

\subsection{Board Size and Firm Performance: Further Analysis}

After establishing a relation between board size and the structure of bank investments and riskiness, we next turn our attention to the geographic and ownership characteristics of the bank. In Models (1) and (2) we examine US banks only, and partition between listed vs. non-listed banks. Results are presented in Table 8 . 
Table 8. Multivariate analysis examining the relation between board size and firm performance, controlling for region and listing status

\begin{tabular}{|c|c|c|c|c|c|c|}
\hline VARIABLES & $\begin{array}{c}(1) \\
\boldsymbol{R O A} \\
\end{array}$ & $\begin{array}{c}(2) \\
\boldsymbol{R O A} \\
\end{array}$ & $\begin{array}{c}(3) \\
R O A \\
\end{array}$ & $\begin{array}{c}(4) \\
\boldsymbol{R O A} \\
\end{array}$ & $\begin{array}{c}(5) \\
\boldsymbol{R O A}\end{array}$ & $\begin{array}{c}(6) \\
\text { ROA } \\
\end{array}$ \\
\hline \multirow[t]{2}{*}{ Constant } & 2.114 & 1.732 & -1.461 & $4.677 * * *$ & $6.086 * * *$ & $4.348^{* * *}$ \\
\hline & [1.57] & {$[0.96]$} & {$[-0.91]$} & [9.26] & {$[6.66]$} & [4.02] \\
\hline \multirow[t]{2}{*}{ logBoardSize } & $1.115^{* * *}$ & 0.438 & 0.104 & $0.257^{*}$ & $0.839 * * *$ & 0.285 \\
\hline & [2.63] & {$[0.81]$} & {$[0.11]$} & {$[1.76]$} & [2.64] & {$[1.28]$} \\
\hline \multirow[t]{2}{*}{$\operatorname{logBoardSize} e^{2}$} & $-0.238 * * *$ & -0.091 & -0.049 & -0.044 & $-0.208 * * *$ & -0.080 \\
\hline & {$[-2.64]$} & {$[-0.79]$} & {$[-0.27]$} & {$[-1.39]$} & {$[-2.69]$} & {$[-1.50]$} \\
\hline \multirow[t]{2}{*}{ logAssets } & $0.136^{* * * *}$ & $0.118 * * *$ & $-0.075^{*}$ & 0.006 & $0.154 * * *$ & $0.150 * * *$ \\
\hline & [4.89] & [3.06] & {$[-1.71]$} & {$[0.52]$} & [4.24] & [6.38] \\
\hline \multirow[t]{2}{*}{ Leverage } & $-6.861 * * *$ & $-3.865 * *$ & $-6.155^{* * *}$ & $-5.196^{* * *}$ & $-7.767 * * *$ & $-4.405 * * *$ \\
\hline & {$[-4.41]$} & {$[-2.375]$} & {$[-12.12]$} & {$[-14.59]$} & {$[-15.14]$} & {$[-11.20]$} \\
\hline Year & Yes & Yes & Yes & Yes & Yes & Yes \\
\hline Industry Controls & Yes & Yes & Yes & Yes & Yes & Yes \\
\hline Country Controls & Yes & Yes & Yes & Yes & Yes & Yes \\
\hline Observations & 6,865 & 3,116 & 9,729 & 58,420 & 17,546 & 30,008 \\
\hline R-squared & 0.310 & 0.242 & 0.331 & 0.188 & 0.291 & 0.134 \\
\hline
\end{tabular}

Note. Models (1) \& (2) examine listed and non-listed US firms, respectively. Models (3) \& (4) examine listed and non-listed EU firms, respectively. Models (5) \& (6) examine listed and non-listed non US/EU firms, respectively. ROA is return on assets, BoardSize is the number of directors sitting on board, Assets is the book value of assets, Leverage is one minus the book value of equity normalized by total assets. $* * *, * * *$ indicate significance at $1 \%, 5 \%$, and $10 \%$ respectively. All regressions are conducted using OLS and clustering bank id. The time period is 1990-2013.

In Model (1) we see that the inverted U-curve relation holds for US listed banks, but does not in non-listed privately owned US banks (Model 2). In Models (3) and (4) we repeat the same analysis for EU banks, where we see that for both privately or publicly held banks, the inverted U-curve relation does not hold. Finally, in Models (5) and (6) we split the sample among listed vs. non-listed firms in non-EU and non-US jurisdictions. We see that inferences still hold.

In sum, we see that our results in Table 5 are driven by listed firms rather than non-listed ones, as predicted through agency theory. Results also indicate that this relation is driven by US and international non-EU banks. These results are perplexing, and we can only speculate as to what are the differences across banks in the EU vs. the rest of the world. This could be due to a number of reasons. First, it could be the case that because internal governance mechanisms are more active in the EU (monitoring by government, capital providers, and family owners), as such, explicit governance mechanisms such as board size are less relevant in an EU context (see Schulze et al., 2001). Second, it is altogether possible that family-oriented capital markets in the EU impose inefficiencies on optimal board sizes. Finally, our non-results in the EU could be a statistical artifact of our data: it could be because EU banks have inherently larger boards while performance is similar to non EU banks. However, further analysis reveals that the non-relation in EU banks is not because EU banks have inherently larger boards with less variability: in untabulated tests we see that the average board size for EU banks is composed of 13 members, which is not different in size to the board size of international or US banks (12 and 13 members, respectively). Further untabulated analysis reveals that the results on EU based banks are not due to the time period or type of bank. Moreover, restricting our sample to commercial and investment banks, again, results remain unchanged.

\subsection{Board Size and the Crisis Years}

Prior sections establish an inverted U-curve relation between board size and performance, which we attribute to differential banking strategies that affect bank riskiness. If this explanation were to be true then exogenous external shocks would affect riskier strategies more strongly. Hence we next examine the relation between board size and performance during the crisis years. Results are presented in Table 9. 
Table 9. Multivariate analysis examining the relation between board size and firm performance during the crisis

\begin{tabular}{|c|c|c|c|c|}
\hline VARIABLES & $\begin{array}{c}(1) \\
\text { ROA }\end{array}$ & $\begin{array}{c}(2) \\
\Delta \text { Loan Loss }\end{array}$ & $\begin{array}{c}(3) \\
\Delta \text { Other Expense }\end{array}$ & $\begin{array}{c}\text { (4) } \\
\Delta \text { Dividends }\end{array}$ \\
\hline \multirow[t]{2}{*}{ Constant } & 4.4981 & $0.0032 * * *$ & 0.0032 & -0.0005 \\
\hline & {$[1.56]$} & [6.517] & [1.607] & {$[-0.671]$} \\
\hline \multirow[t]{2}{*}{ logBoardSize } & 0.0205 & 0.0000 & $0.0002 *$ & $0.0001 * * *$ \\
\hline & [0.667] & {$[0.335]$} & {$[1.692]$} & [2.870] \\
\hline \multirow[t]{2}{*}{$\operatorname{logBoardSize} * 2010$} & 0.0078 & $0.0012^{* * * *}$ & $0.0040^{* * *}$ & -0.0001 \\
\hline & {$[0.158]$} & [4.677] & [7.337] & {$[-0.620]$} \\
\hline \multirow[t]{2}{*}{$\log$ BoardSize $* 2009$} & $0.1713^{* * *}$ & $-0.0010 * * *$ & $-0.0006^{*}$ & -0.0001 \\
\hline & [3.305] & {$[-4.321]$} & {$[-1.693]$} & {$[-0.901]$} \\
\hline \multirow[t]{2}{*}{$\operatorname{logBoardSize} * 2008$} & $0.1139 * *$ & $-0.0015^{* * *}$ & $-0.0059 * * *$ & $-0.0005^{* * *}$ \\
\hline & {$[2.330]$} & {$[-7.116]$} & [-7.757] & {$[-3.588]$} \\
\hline \multirow[t]{2}{*}{$\operatorname{logBoardSize} * 2007$} & $-0.0937 * *$ & -0.0002 & 0.0002 & 0.0001 \\
\hline & [-2.047] & {$[-1.374]$} & {$[0.537]$} & {$[0.500]$} \\
\hline \multirow[t]{2}{*}{$\operatorname{logBoardSize} * 2006$} & $-0.1433 * * *$ & -0.0001 & 0.0005 & 0.0002 \\
\hline & {$[-3.080]$} & {$[-0.542]$} & {$[1.500]$} & {$[0.980]$} \\
\hline \multirow[t]{2}{*}{$\operatorname{logBoardSize} * 2005$} & $-0.1111^{* *}$ & $-0.0003^{*}$ & $0.0007 * *$ & -0.0000 \\
\hline & {$[-2.457]$} & {$[-1.732]$} & {$[2.051]$} & {$[-0.020]$} \\
\hline \multirow[t]{2}{*}{$\operatorname{logBoardSize} * 2004$} & -0.0208 & $0.0004 *$ & 0.0006 & -0.0001 \\
\hline & {$[-0.483]$} & {$[1.923]$} & [1.494] & {$[-0.819]$} \\
\hline \multirow[t]{2}{*}{ logAssets } & $0.0808^{* * *}$ & $0.0000 *$ & -0.0000 & -0.0000 \\
\hline & [8.839] & [1.805] & {$[-0.631]$} & {$[-1.405]$} \\
\hline \multirow[t]{2}{*}{ Leverage } & $-5.7886 * * *$ & $0.0018^{* * *}$ & $-0.0021 * * *$ & $-0.0005^{*}$ \\
\hline & {$[-27.960]$} & [4.195] & {$[-3.391]$} & {$[-1.886]$} \\
\hline Year Controls & Yes & Yes & Yes & Yes \\
\hline Industry Controls & Yes & Yes & Yes & Yes \\
\hline Country Controls & Yes & Yes & Yes & Yes \\
\hline Observations & 129,140 & 95,409 & 108,381 & 113,226 \\
\hline R-squared & 0.205 & 0.025 & 0.015 & 0.002 \\
\hline
\end{tabular}

Note. ROA is return on assets, BoardSize is the number of directors sitting on board, Assets is the book value of assets, Leverage is one minus the book value of equity normalized by total assets, $\Delta$ Loan Loss is the change in loan losses, $\Delta$ OtherExpense include write-downs, impairments, and other crisis related losses, $\Delta$ Dividends is the change in dividends. All dependent variables are normalized by total assets. *, $* *, * * *$ indicate significance at $1 \%, 5 \%$, and $10 \%$ respectively. All regressions are conducted using OLS and clustering bank id. The time period is $1990-2013$.

We repeat our multivariate regressions by utilizing an interactive dummy $\log$ BoardSize ${ }^{*}$ YrO8 (we also present interactive dummies for all the years adjoining the crisis year). In Model (1) we examine ROA as the dependent variable, where results indicate that the interaction variable is positive and significant in both of 2008 and 2009 $(t$-statistic $=2.33$ and 3.30, respectively), hence evidence that riskier banking strategies suffered bigger losses. However, and as expected, these riskier strategies adopted by smaller boards had higher payoffs in the boom years, as evidenced by the negative interaction on the years 2005-2007.

In Models (2)-(4) we break down these performance effects into individual categories. In Model (2) we examine the same interactive variables in relation to the change in loan losses (chLoanLoss), where we see that loan losses were lower for larger board banks in both 2008 and 2009. In Model (3) we examine the change in other expenses (chOtherExpense), which would include write-downs, impairments, and other crisis related losses. We see that in both 2008 and 2009 such losses were magnified for firms with small boards as compared to larger boards. Finally, in Model (4) we examine the change in dividends (chDividend), with similar inferences.

This performance leading up to the crisis and subsequent to it is a curious finding from a performance perspective. It is not the case that good governance as characterized by smaller boards (as frequently argued), induced prudent investment and decision making, where profits were more modest in the boom but the slide was prevented when the bubble burst. On the contrary, banks with smaller boards with alleged efficient and agile decision making were revealed to be the riskier ones, as evidenced by the inferior performance during the crisis.

\subsection{Board Size and Performance: Other Robustness}

Having established a statistically significant relation between board size and performance in banks, and having argued for a risk-based explanation, we next proceed to a number of robustness tests to support our main 
findings. A dominant paradigm in governance research is that corporate governance is an endogenously determined construct (Hermalin \& Weisbach, 1998). In this specific case, it could be the case that firms in increase board size in order to enhance the resource providing, advising, and monitoring role of the board (see Mizruchi, 1983). Hence, board size is not an exogenous variable, but is jointly determined alongside performance by other exogenous factors. The current research design does not allow us to conduct finer analysis to address this issue. However, as a partial remedy, we conduct two analyses: a three-stage least squared estimation, and a Granger (1967) type analysis. Results are reported in Table 10.

Table 10. Three stage least-squares analysis examining the relation between board size and firm performance

\begin{tabular}{|c|c|c|c|}
\hline \multicolumn{3}{|c|}{ (2) } & \multirow{2}{*}{$\begin{array}{c}(1) \\
\operatorname{logBoardSize}\end{array}$} \\
\hline VARIABLES & ROA & & \\
\hline \multirow[t]{2}{*}{ Constant } & 0.3325 & Constant & $0.7325 * * *$ \\
\hline & [0.304] & & [9.604] \\
\hline \multirow[t]{2}{*}{ logBoardSize } & $12.7505 * * *$ & lagCompetition & $0.8650 * * *$ \\
\hline & [15.391] & & {$[14.751]$} \\
\hline \multirow[t]{2}{*}{$\operatorname{logBoardSize} e^{2}$} & $-2.7025 * * *$ & laglogAssets & $0.1105^{* * * *}$ \\
\hline & {$[-14.919]$} & & {$[100.257]$} \\
\hline \multirow[t]{2}{*}{ logAssets } & $0.0852 * * *$ & lagLeverage & $-0.3012 * * *$ \\
\hline & [10.645] & & {$[-21.392]$} \\
\hline \multirow[t]{8}{*}{ Leverage } & $-6.9957 * * *$ & Private Credit & $-0.0994 * * *$ \\
\hline & {$[-79.663]$} & & {$[-10.852]$} \\
\hline & & $\triangle G D P$ & $-0.0151^{* * *}$ \\
\hline & & & {$[-12.885]$} \\
\hline & & Equity Size & -0.0000 \\
\hline & & & {$[-0.292]$} \\
\hline & & Currency Outside Banks & $0.0271 * * *$ \\
\hline & & & [33.785] \\
\hline Industry Controls & Yes & & Yes \\
\hline Year Controls & Yes & & Yes \\
\hline Observations & 80,990 & & 80,990 \\
\hline R-squared & 0.130 & & 0.199 \\
\hline
\end{tabular}

Note. ROA is return on assets, BoardSize is the number of directors sitting on board, Assets is the book value of assets, Leverage is one minus the book value of equity normalized by total assets. Competition is the herfindahl index of banks in each country/year cluster, Private Credit is the total value of non-bank lending in a country, $\triangle G D P$ is the change in GDP, Equity Size is the size of public equity markets, Currency Outside Banks is the value of liquid capital not deposited in banks. *, **, *** indicate significance at $1 \%, 5 \%$, and $10 \%$ respectively. The time period is 1990-2013.

In the three stage least-squares analysis we utilize board size as a dependent variable in the first stage regression, as a function of lagged firm performance, lagged total assets, the competitive environment as measured by the herfindahl index of banks in each year/country cluster, and a number of regional/macroeconomic factors (the presence of private credit, the important of capital markets, GDP growth, and currency outside of banks - see Shleifer and Vishny (1997)), and industry, year, and country controls. In the second stage, we run our standard regression per Model (1) of Table 4. Results indicate that the inverted U-curve relation is significant and robust (in fact, our $t$-statistic increases 3 fold).

In further unreported tests, we take advantage of the time dimension in our panel by conducting a Granger (1969) type test where we lag the dependent variable and use it as an additional independent variable. This would test the relation between board size and performance, above and beyond the time dependency of board size-performance itself. Our inverted u-curve remains intact, thus confirming our main results.

As a final set of untabulated robustness tests, we additionally control for a number of variables in multivariate regression settings. So far our analysis has been parsimonious, where we present regressions with firm size, leverage, year, sub-industry, and year controls. Next, we augment our main model (Model (1) of Table 4), with additional controls: we introduce fixed assets, the net interest margin, the loan loss provision, trading assets, the cash balance, the standard deviation of ROA, and the level of loans. Inferences remain intact, but also more interestingly, the robustness of the results indicate that board size is an independent and orthogonal factor that describes the performance of banks. In yet another set of robustness tests, controlling for the Shleifer and Vishny 
(1997) country specific variables of property rights, the independence of the judiciary, the presence of liquidation courts or specialized commerce related courts, the average time to payment of liabilities, and the legal tradition of the country (UK law, French law, or Germanic law), leaves inferences unchanged.

\section{Conclusion}

Prior studies have found conflicting results regarding the board size-performance relation. The alternating views are that of an agency explanation, or a resource dependency one. Utilizing an extensive global sample, this study extends the literature in a number of important ways: first, we examine the relation between board size and firm performance for the banking industry, an important industrial grouping that has not been examined in this dimension. Second, we examine an extensive global bank database of public and private firms, providing more generalizable and more nuanced evidence. Third, we find that an inverted u-curve characterizes the board size-performance relation, especially for publicly owned non-EU firms. Fourth, we provide for a risk-based explanation, where firms with smaller boards follow less traditional banking strategies characterized by higher risk. Consequently, we find a positive board size-performance relation during the 2008 global credit crisis, indicating that in times of distress, more traditional and less risky banks had better performance.

Our results have important policy implications, given the prevailing political/regulatory post-crisis. Corporate governance arrangements have been viewed as one of the main causal factors, our results shed light on the role of corporate governance during the crisis. Specifically, we show that banks with larger boards performed better in 2008, as such providing clear recommendations regarding the issue of board size and performance: it is not necessarily the case that compact smaller boards with fast decision making systems are the way forward.

This study has a number of limitations. Endogeneity and reverse causality is a concern throughout. We have tried some statistical designs to alleviate such concerns, but our results suggest statistical correlations and not causal factors. As such, board size represents a firm characteristic that is related to firm performance, independent and orthogonal to other causal factors. Finally, our results are valid as long as no omitted variable correlated with the BoardSize measure affects ROA. Additional work will address, gathering better and more extensive data, and examine more nuanced settings, to examine these issues when possible.

\section{Acknowledgments}

This paper has received helpful comments and suggestions from Santhosh Gowda, Brian Rountree, Anil Makhija, Steve Crawford, Richard Price, Robert Watson, John Barrios, Pietro Bianchi, Antonio Parbonetti, and Nisreen Salti. Garen Markarian thanks the Spanish Ministry of Science and Innovation (grant n. SEJ2007-67582-CO2-01). We thank seminar participants at the AAA annual meeting in Denver, and the EAA annual meeting in Rome.

\section{References}

Adams, R., \& Mehran, H. (2012). Bank board structure and performance: Evidence for large bank holding companies. Journal of Financial Intermediation, 21(2), 243-267. https://doi.org/10.1016/j.jfi.2011.09.002

Aebi, V., Sabato, G., \& Schmid, M. (2009). Risk management, corporate governance, and bank performance in the financial crisis. Journal of Banking \& Finance, 36(12), 3213- 3226. https://doi.org/10.1016/j.jbankfin.2011.10.020

Baranchuk, N., \& Dybvig, P. H. (2009). Consensus in Diverse Corporate Boards. Review of Financial Studies, 22(2), 715-747. https://doi.org/10.12691/jfa-2-4-2

Beiner, D., \& Schmid, Z. (2006). An integrated framework of corporate governance and firm valuation. European Financial Management, 12, 249-283. https://doi.org/10.1111/j.1354-7798.2006.00318.x

Beltratti, A., \& Stulz, R. M. (2012). The credit crisis around the globe: why did some banks perform better? Journal of Financial Economics, 105(1), 1-17. https://doi.org/10.1016/j.jfineco.2011.12.005

Benjamin, E. H., \& Michael, S. W. (1998). Endogenously Chosen Boards of Directors and Their Monitoring of the CEO. The American Economic Review, 88(1), 96-118.

Berger, A. N., \& Bouwman, C. H. S. (2013). How does capital affect bank performance during financial crises? Journal of Financial Economics, 109(1), 146-176. https://doi.org/10.1016/j.jfineco.2013.02.008

Berger, A. N., \& Humphrey, D. B. (1997). Efficiency of financial institutions: International survey and directions for future research. European Journal of Operational Research, 98(2), 175-212. https://doi.org/10.2139/ssrn.2140

Bhagat, S., \& Black, B. (1999). The Uncertain Relationship between Board Composition and Firm Performance. 
Business Lawyer, 54, 921-963. https://doi.org/10.2139/ssrn.11417

Boyd, J. H., \& Runkle, D. (1993). Size and performance of banking firms: Testing the predictions of theory. Journal of Monetary Economics, 31(1), 47-67. https://doi.org/10.1016/0304-3932(93)90016-9

Brunello, G., Graziano, C., \& Parigi, B. M. (2003). CEO turnover in insider-dominated boards: The Italian case. Journal of Banking and Finance, 27, 1027-1051. https://doi.org/10.1016/S0378-4266(02)00244-3

Burns, J. (2004). Seven Former SEC Heads Endorse Independent Fund Co Chairman. The Wall Street Journal Online, June 15.

Cameron, A. C., Gelbach, J. B., \& Miller, D. L. (2011). Robust inference with multiway clustering. Journal of Business and Economic Statistics, 29(2), 238-249. https://doi.org/10.1198/jbes.2010.07136

Chesney, M., Stromberg, J., \& Wagner, A. F. (2010). Risk-taking incentives, governance, and losses in the financial crisis. Swiss Finance Institute research paper. Retrieved from http://ssrn.com/abstract=1595343.

Coles, J. L., Daniel, N. D., \& Naveen, L. (2008). Boards: Does one size fit all? Journal of Financial Economics, 87(2), 329-356. https://doi.org/10.1016/j.jfineco.2006.08.008

Conyon, M. J., \& Simon, I. P. (1998). Board control, remuneration committees, and top management compensation. Academy of Management Journal, 41(2), 146-157. https://doi.org/10.2307/257099

Dalton, D. R., Daily, C. M., Ellstrand, A. E., \& Johnson, J. L. (1998). Meta-analytic reviews of board composition, leadership structure, and financial performance. Strategic Management Journal, 19(3), 269-290. https://doi.org/10.1002/(SICI)1097-0266(199803)19:3<269::AID-SMJ950>3.0.CO;2-K

Dessein, W. (2002). Authority and Communication in Organizations. Review of Economic Studies, 69, 811-838. https://doi.org/10.1111/1467-937X.00227

Eisenberg, T., Sundgren, S., \& Wells, M. (1998). Larger Board Size and Decreasing Firm Value in Small Firms. Journal of Financial Economics, 48, 35-54. https://doi.org/10.1016/S0304-405X(98)00003-8

Erkens, D. H., Mingyi, H., \& Matos, P. (2012). Corporate governance in the 2007-2008 financial crisis: Evidence from financial institutions worldwide. Journal of Corporate Finance, 18(2), 389-411. https://doi.org/10.1016/j.jcorpfin.2012.01.005

Fahlenbrach, R., \& Rene, S. (2011). Bank CEO incentives and the credit crisis. Journal of Financial Economics, 99, 11-26. https://doi.org/10.3386/w15212

Fama, E., \& MacBeth, J. (1973). Risk, return, and equilibrium: Empirical tests. Journal of Political Economy, 81(3), 607-636. https://doi.org/10.1086/260061

Francis, B., Hasan, I., Park, J. C., \& Wu, Q. (2014). Gender differences in financial reporting decision-making: Evidence from accounting conservatism. Contemporary Accounting Research, forthcoming.

Granger, C. W. J. (1969). Investigating causal relation by econometric and cross-sectional method. Econometrica, 37, 424-438. https://doi.org/10.2307/1912791

Gustavo, G., Roni, M., \& Bhaskaran, S. (2002). Are Dividend Changes a Sign of Firm Maturity? The Journal of Business, 75(3), 387-424. https://doi.org/10.1086/339889

Harris, M., \& Artur, R. (1991). The Theory of Capital Structure. Journal of Finance, 46, 297-356. https://doi.org/10.1111/j.1540-6261.1991.tb03753.x

Hermalin, B., \& Michael, S. W. (1998). Endogenously Chosen Boards of Directors and Their Monitoring of the CEO. American Economic Review, 88(1), 96-118.

Huther, J. (1997). An empirical test of the effect of board size on firm efficiency. Economics Letter, 54(3), 259-264. https://doi.org/10.1016/S0165-1765(97)00035-9

IMF. (2009). Global Financial Stability Report. GFSR Market Update, January.

Institute of International Finance. (2009). Compensation in financial services industry progress and the agenda for change. Washington DC.

Iyer, S., Takeshi, N., Ramesh, P. R., \& Gary, W. S. (2010). Risk management, corporate governance, and bank holding company performance in the financial crisis.

Jensen, M. C. (1993). The modern industrial revolution, exit and the failure of internal control systems. Journal of Finance, 48, 831-880. https://doi.org/10.1111/j.1540-6261.1993.tb04022.x 
Lehn, K., Patro, S., \& Zhao, M. (2009). Determinants of the size and structure of corporate boards: 1935-2000. Financial Management, 38, 241-274. https://doi.org/10.1111/j.1755-053X.2009.01055.x

Lipton, M., \& Lorsch, J. W. (1992). A Modest Proposal for Improved Corporate Governance. The Business Lawyer, 48(1).

Livne, G., Markarian, G., \& Mironov, M. (2013). Investment horizon, risk, and compensation in the banking industry. Journal of Banking \& Finance, 37(9), 3669-3680. https://doi.org/10.1016/j.jbankfin.2013.05.021

Mark, S. M. (1983). The Academy of Management Review, 8(3), 426-435.

Mizruchi, M. S. (1983). Who controls whom? An examination of the relation between management and board of directors in large American corporations. Academy of Management Review, 8, 426-435. https://doi.org/10.5465/AMR.1983.4284426

Schulze, W. S., Lubatkin, M. H., Dino, R. N., \& Buchholtz, A. K. (2001). Agency Relationships in Family Firms: Theory and Evidence. https://doi.org/10.1287/orsc.12.2.99.10114

Shijun, C. (2008). Board size and the variability of corporate performance. Journal of Financial Economics, 87(1), 157-176. https://doi.org/10.1016/j.jfineco.2006.10.006

Shleifer, A., \& Vishny, R. W. (1997). A Survey of Corporate Governance. The Journal of Finance, 52(2), 1540-6261. https://doi.org/10.1111/j.1540-6261.1997.tb04820.x

Stickney, C., Weil, R., Schipper, K., \& Francis, J. (2009). Financial Accounting: an Introduction to Concepts, Methods and Uses. South-Western Cengage Learning.

Thompson, S. B. (2009). Simple formulas for standard errors that cluster by both firm and time. Retrieved from http://ssrn.com/abstract=914002.

Upadhyay, A., \& Ram, S. (2011). Board Size, Corporate Information Environment and Cost of Capital. Journal of Business Finance \& Accounting, 38(9-10), 1468-5957. https://doi.org/10.1111/j.1468-5957.2011.02260.x

Yermack, D. (1996). Higher market valuation of firms with a small board of directors. Journal of Financial Economics, 40, 185-211. https://doi.org/10.1016/0304-405X(95)00844-5

Zimmerman, J. L. (1983). Taxes and firm size. Journal of Accounting and Economics, 5, 119-149. https://doi.org/10.1016/0165-4101(83)90008-3

Zingales, L. (1994). The value of voting right: A study of the Milan stock exchange experience. Review of Financial Studies, 7, 125-148. https://doi.org/10.1093/rfs/7.1.125

\section{Notes}

Note 1. See for example, Harris and Raviv (2008), for an analytical examination; Coles et al. (2008) for conflicting empirical findings; and Eisenberg, Sundgren, and Wells, 1998, for an extension into small Finnish firms. Lehn, Patro, and Zhao (2009), for a 65-year examination; Beiner, Drobetz, Schmid, and Zimmermann (2003), in sociology; Huther (1997), in economics, and Dalton, Daily, Johnson, and Ellstrand (1999), for a meta-analysis in management.

Note 2. In 2009, the OECD published a 3 phase report that identified shortcoming and recommended changes to practices encompassing executive compensation, risk management, board practices, and the exercise of shareholder rights.

Note 3. Jane Diplok, executive committee member of IOSCO, recently declared that the crisis "was a result of poor governance in institutions which had a poor regulatory framework."

Note 4. Nell Minnow, co-founder of the Corporate Library, recently declared: "the recent volatility proved that the need for better corporate governance has never been clearer or more pressing."

Note 5. Bankscope discontinued reporting "NOBMO" (the size of the board of directors) in 2013.

Note 6. Yermack (1996, p. 200) observes that there is high director turnover, with little effect on board size. He finds a positive, but weak, relation between changes in firm size and board size, where a firm has to quadruple in size before appointing an extra director.

Note 7. There is little firm specific time-series variation in board size in our panel, especially in the earlier periods, hence we are not able to conduct a firm-fixed effects specification.

Note 8. There are multiple dates that can be considered the "period" of the crisis (see Fahlrenbach and Stulz, 
2011), in our calendar year data the biggest drop in performance is the year 2008, which we use as a focal point for our analysis.

Note 9. We do a more formal examination in attempting to find an "optimal" board size. This is done by solving for "logBoardSize" in Model (1) of Table 5. Results indicate that the optimal board size is at around 11 directors.

Note 10. Further unreported analysis indicates, again, an inverted u-curve relation between asset size and performance.

Note 11. Results on Model (5), combined with results on Model (1), and untabulated results that show board size is unrelated to either of the loan loss reserve and loan loss provision, indicate that the positive relation between board size and the net interest margin obtained in Model (1) is due to a lower cost of capital, and not the riskiness of the loan book.

\section{Copyrights}

Copyright for this article is retained by the author(s), with first publication rights granted to the journal.

This is an open-access article distributed under the terms and conditions of the Creative Commons Attribution license (http://creativecommons.org/licenses/by/4.0/). 